\title{
RELIGION AROUND \\ JOHN DONNE
}

J O S H UA E G H A R D T

THE PENNSYLVANIA STATE UNIVERSITY PRESS

UNIVERSITY PARK, PENNSYLVANIA 
Retigion Around vol. 4 inf intint

Pete R IVE R KAUf MAN, Founding Editor

Books in the Religion Around series examine the religious forces surrounding cultural icons. By bringing religious background into the foreground, these studies give readers a greater understanding of and appreciation for individual figures, their work, and their lasting influence. 
Library of Congress Cataloging-in-Publication Data

Names: Eckhardt, Joshua, author.

Title: Religion around John Donne / Joshua Eckhardt.

Other titles: Religion around.

Description: University Park, Pennsylvania : The Pennsylvania State University Press, [2019] | Series: Religion around I Includes bibliographical references and index.

Summary: "Explores the ways in which the religious controversies and beliefs that surrounded John Donne were circulated in late Elizabethan and early Stuart England"-Provided by publisher.

Identifiers: LCCN 2019000514 I ISBN 9780271083377 (cloth : alk. paper)

Subjects: LCSH: Donne, John, 1572-1631-Religion. I Donne, John, 1572-1631Library. I Books-England-Religious aspects-History-17th century. I

Manuscripts, English-Religious aspects-History-17th century.

Classification: LCG PR224,8.E25 2019 | DDC 821/.3-dc23

LC record available at https://lccn.loc.gov/2019000514

Copyright (C) 2019 The Pennsylvania State University

All rights reserved

Printed in the United States of America

Published by The Pennsylvania State University Press,

University Park, PA 16802-1003

The Pennsylvania State University Press is a member of the Association of University Presses.

It is the policy of The Pennsylvania State University Press to use acid-free paper. Publications on uncoated stock satisfy the minimum requirements of American National Standard for Information Sciences-Permanence of Paper for Printed Library Material, ANSI Z39.4,8-1992. 